\title{
A Huge Mass in the Liver: Plasmacytoma
}

\author{
Karaciğerde Dev Kitle: Plazmasitom
}

Tahir Alper Cinli1, (D) Osman Yokuş11, (D) Hasan Göze1, (D) Gülben Erdem Huq², (D) İstemi Serin1

1 University of Health Sciences Turkey, Istanbul Training and Research Hospital, Clinic of Hematology, Istanbul, Turkey

2University of Health Sciences Turkey, Istanbul Training and Research Hospital, Clinic of Pathology, Istanbul, Turkey

\section{To the Editor,}

In patients diagnosed with multiple myeloma (MM), the diagnosis of extramedullary MM (EMM) is made by different imaging methods and biopsy for the presence of soft tissue masses. EMM is associated with high stage and poor prognosis $[1,2,3]$. The frequency of EMM was found to be only $3.7 \%[3]$.

A 55-year-old male patient applied to the emergency department with abdominal pain and multiple skin lesions (Figures $1 \mathrm{~A}$ and 1B). At the time of the initial diagnosis, hemoglobin was 7.6 $\mathrm{g} / \mathrm{dL}$, creatinine was $2.04 \mathrm{mg} / \mathrm{dL}$, urea was $53 \mathrm{mg} / \mathrm{dL}$, total protein was $123.8 \mathrm{~g} / \mathrm{L}$, albumin was $18.4 \mathrm{~g} / \mathrm{L}$, corrected calcium was $11.3 \mathrm{mg} / \mathrm{dL}$, lactate dehydrogenase (LDH) was $176 \mathrm{U} / \mathrm{L}, \beta 2-$ microglobulin was $12.68 \mathrm{mg} / \mathrm{L}$, and serum free kappa light chain was $330 \mathrm{mg} / \mathrm{L}$ with kappa light chain monoclonality detected by serum immunofixation electrophoresis. In the abdominal magnetic resonance imaging (MRI) of the patient, a mass lesion in the liver with a size of $196 \times 187 \times 230 \mathrm{~mm}$ and a malignant appearance was detected (Figure 2).

As determined by a Tru-Cut biopsy of the mass, a monotypic plasmacytic infiltration was present, which was CD20 (-), CD19 weakly suspicious $(+)$, CD79a weak (+), CD3 weak (+), CD138 $(+)$, CD38 (+), kappa (+), lambda (-), CD56 (-), and cyclin D1 (-), resulting in a diagnosis of plasmacytoma/plasma cell neoplasia. In the bone marrow, 3\% mature polytypic plasma cells were detected. Fine-needle aspiration of skin lesions showed monotypic plasma cells (Figure 1C).

A total of 6 sessions of plasmapheresis and hemodialysis were performed due to hyperviscosity and acute renal failure. The treatment was started with bortezomib at $1.3 \mathrm{mg} / \mathrm{m}^{2}$ on days 1-8-15-22, cyclophosphamide at $300 \mathrm{mg} / \mathrm{m}^{2}$ on days $1-8-15$ -22 , and intravenous dexamethasone at $40 \mathrm{mg}$ on days $1-4,9-12$, 17-20, and 25-28. After one course of treatment, hemoglobin was $9.2 \mathrm{~g} / \mathrm{dL}$, creatinine was $0.63 \mathrm{mg} / \mathrm{dL}$, total protein was 76.7 $\mathrm{g} / \mathrm{L}$, albumin was $31.3 \mathrm{~g} / \mathrm{L}$, corrected calcium was $7.2 \mathrm{mg} / \mathrm{dL}$, and $\mathrm{LDH}$ was $140 \mathrm{U} / \mathrm{L}$. Abdominal computed tomography revealed that the mass in the liver had regressed to $14 \mathrm{~mm}$ at its widest part and there were no macroscopically visible skin lesions remaining.
EMM is an aggressive MM subtype. It has shorter overall survival and progression-free survival compared to classical MM $[4,5]$. EMM with a mass in the abdomen does not show symptoms until reaching larger sizes. Such cases manifest with abdominal pain and late obstructive symptoms. The size of these tumors was reported to be $11.9 \mathrm{~cm}$ and only two cases of tumors larger than $15 \mathrm{~cm}$ have been reported in the literature [6]. Most cases with an abdominal mass manifest in the mesentery.

Metastatic tumors often present with irregularly surrounded multilayer appearances, peritumoral edema, and a necrotic hemorrhagic center [7]. With T1-weighted MRI, hepatocellular carcinoma of less than $1.5 \mathrm{~cm}$ is often isointense. Welldifferentiated tumors are often isointense, whereas moderately to poorly differentiated tumors are more often hyperintense $[7,8]$. There is no typical image for the differential diagnosis of EMM.

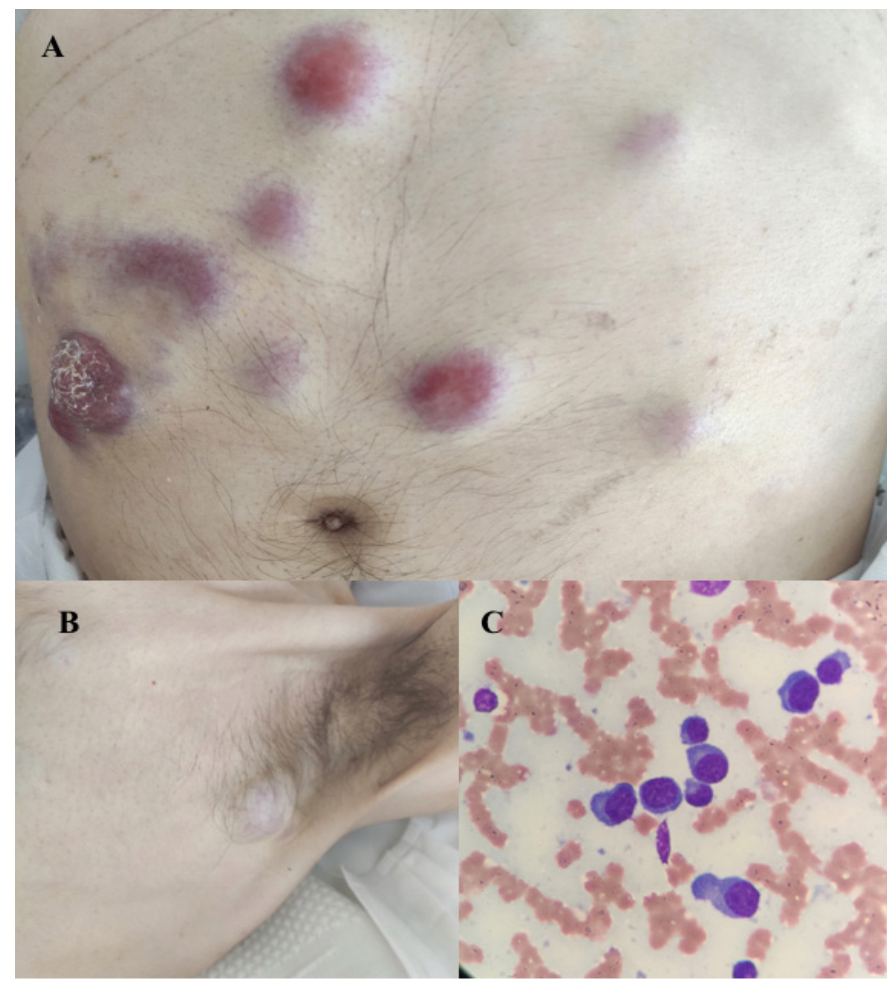

Figure 1. A) Multiple nodular skin lesions on the abdomen; B) axillary mass lesion; $\mathrm{C}$ ) hematoxylin and eosin staining of fineneedle aspiration from an abdominal skin lesion: plasma cells. 


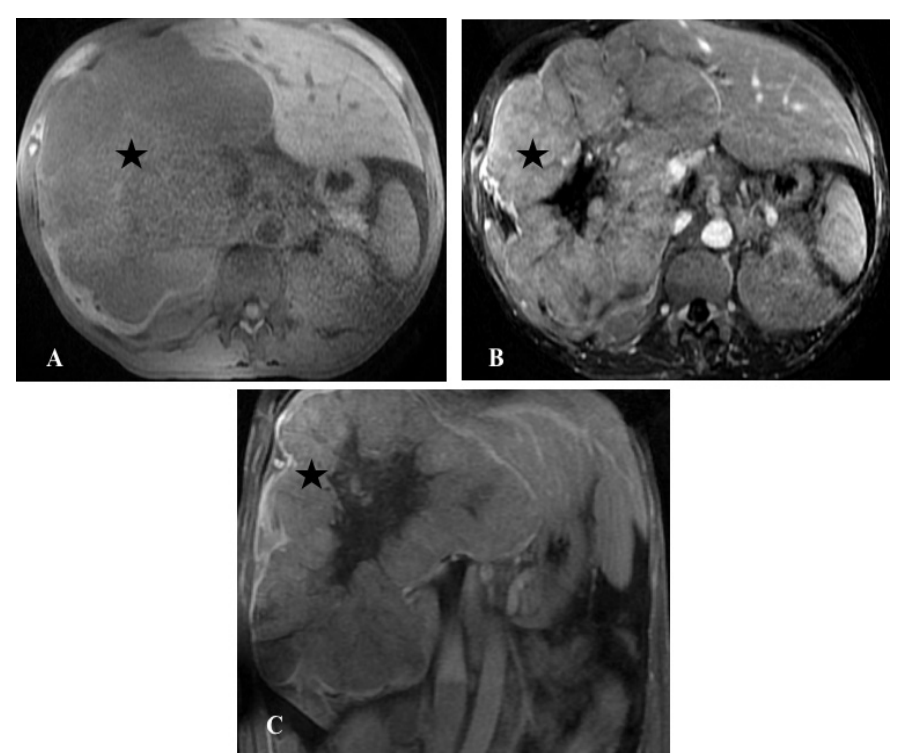

Figure 2. MRI images at initial diagnosis: A) fat-suppressed precontrast T1-weighted series, transverse plane; B) fat-suppressed T1-weighted series, arterial phase, transverse plane; C) fatsuppressed T1-weighted series, parenchymal phase, coronal plane.

In conclusion, this case of EMM is the first of its kind to be reported, with size reaching $20 \mathrm{~cm}$ and, unlike cases in the literature to date, the absence of mesentery localization.

Keywords: Mass in the liver, Multiple myeloma, Plasmacytoma

Anahtar Sözcükler: Karaciğerde kitle, Multipl myelom, Plazmositoma

Informed Consent: Written informed consent was obtained from the patient for publication of this case report and any accompanying images.

\section{Authorship Contributions}

Concept: T.A.C., O.Y., H.G., G.E.H., I.S.; Design: T.A.C., O.Y., H.G., G.E.H., I.S.; Data Collection or Processing: T.A.C., O.Y., H.G., G.E.H., i.S.; Analysis or Interpretation: T.A.C., O.Y., H.G., G.E.H., i.S.; Literature Search: T.A.C., O.Y., H.G., G.E.H., I.S.; Writing: T.A.C., O.Y., H.G., G.E.H., I.S.

Conflict of Interest: No conflict of interest was declared by the authors.

Financial Disclosure: The authors declared that this study received no financial support.

\section{References}

1. Bhutani M, Foureau DM, Atrash S, Voorhees PM, Usmani SZ. Extramedullary multiple myeloma. Leukemia 2020;34:1-20.

2. Rajkumar SV. Multiple myeloma: 2018 update on diagnosis, riskstratification, and management. Am J Hematol 2018;93:981-1114.

3. Gagelmann N, Eikema DJ, lacobelli S, Koster L, Nahi H, Stoppa AM, Masszi T, Caillot D, Lenhoff S, Udvardy $M$, Crawley C, Arcese W, Mariette C, Hunter A, Leleu $X$, Schipperus $M$, Delforge $M$, Pioltelli P, Snowden JA, Itälä-Remes $M$, Musso M, van Biezen A, Garderet L, Kröger N. Impact of extramedullary disease in patients with newly diagnosed multiple myeloma undergoing autologous stem cell transplantation: a study from the Chronic Malignancies Working Party of the EBMT. Haematologica 2018;103:890-897.

4. Malysz J, Talamo G, Zhu J, Clarke LE, Bayerl MG, Ali L, Helm KF, Chung CG. Cutaneous involvement in multiple myeloma (MM): A case series with clinicopathologic correlation. J Am Acad Dermatol 2016;74:878-884.

5. Thambi SM, Nair SG, Benson R. Plasmacytoma of the mesentery. J Postgrad Med 2018;64:255-257.

6. Sevcikova S, Minarik J, Stork M, Jelinek T, Pour L, Hajek R. Extramedullary disease in multiple myeloma - controversies and future directions. Blood Rev 2019;36:32-39.

7. Silva $A C$, Evans JM, McCullough $A E$, Jatoi $M A$, Vargas $H E$, Hara $A K$. MR imaging of hypervascular liver masses: a review of current techniques. Radiographics 2009;29:385-402.

8. Xu H, Li X, Xie JX, Yang ZH, Wang B. Diffusion-weighted magnetic resonance imaging of focal hepatic nodules in an experimental hepatocellular carcinoma rat model. Acad Radiol 2007;14:279-286. 